\title{
Antibacterial and Antioxidant Activities of Liquidambar Orientalis Mill. Various Extracts Against Bacterial Pathogens Causing Mastitis
}

\author{
Gulten Okmen $^{1 *}$, Zafer Cantekin ${ }^{2}$, Mohammmad Intakhab Alam³, Onur Turkcan', Yasar Ergun ${ }^{4}$ \\ ${ }^{I}$ Department of Biology, Faculty of Science, Mugla Sitki Kocman University, 48000, Mugla, Turkey \\ ${ }^{2}$ Department of Microbiology, Faculty of Veterinary Medicine, Mustafa Kemal University, 31060, Hatay, Turkey \\ ${ }^{3}$ Department of Medical Microbiology, 27000, Gaziantep, Turkey \\ ${ }^{4}$ Department of Obstetrics and Gynecology, Faculty of Veterinary Medicine, Mustafa Kemal University, 31060, Hatay, Turkey \\ \begin{tabular}{ll}
\hline A R T ICLE IN F O A B S TR A C T \\
\hline
\end{tabular} \\ Research Article \\ Received 17 January 2017 \\ Accepted 06 March 2017 \\ Keywords: \\ Antibiotic resistance \\ Antibacterial activity \\ Antioxidant activity \\ Liquidambar orientalis \\ Mastitis \\ Staphylococci \\ *Corresponding Author: \\ E-mail: gultenokmen@gmail.com

\begin{abstract}
Antibiotic resistance is being constantly developed worldwide. Coagulase Negative Staphylococci (CNS) and Staphylococcus aureus are common causes of bovine subclinical mastitis. Bioactive compound of medicinal plants shows anti-microbial, antimutagenic and anti-oxidant effects. The anti-bacterial and anti-oxidant activities of Liquidambar orientalis (L. orientalis) extracts on subclinical mastitis causing bacteria in cows have not been reported to date. The aim of the present study was to examine antibacterial and anti-oxidant effects of $L$. orientalis leaf extracts on $S$. aureus and CNS isolated from cows with subclinical mastitis symptoms. In this study, $3.2 \mathrm{mg} / \mathrm{mL}$ minimum inhibitory concentration (MIC) of ethanol extracts of $L$. orientalis has shown to be a most potent anti-bacterial and anti-oxidant for all isolated bacterial species from mastitis cows. In this study, it was investigated anti-bacterial and anti-oxidant potentials of acetone, methanol and ethanol extracts of the L. orientalis. The acetone extract showed maximum inhibition zone against $S$. aureus numbered $17(12 \mathrm{~mm})$. In addition to antibacterial properties, anti-oxidant activity of $L$. orientalis extract was examined by ABTS [2,2'-azino-bis (3-ethylbenzothiazoline-6-sulphonic acid)] free radical assay. Trolox was used as a positive control anti-oxidant. Ethanol extract exhibited a strong anti-oxidant activity like Trolox anti-oxidant which was effective at $2.58 \mathrm{mM}$ concentration. Bioactive compounds of sweet gum may be useful to screening mastitis causing bacteria for clinical applications.
\end{abstract}

DOI: https://doi.org/10.24925/turjaf.v5i8.883-887.1163

\section{Introduction}

Mastitis is an inflammatory disease of the breast that is frequently encountered in dairy cattle which leads to serious economic losses of about $\$ 35$ billion globally (Watts, 1988; Bramley et al., 1996; Wellenberg et al., 2002). Among the bacterial pathogens of mastitis, Staphylococcus aureus (S. aureus) has been reported for many years as the most frequently isolated agent (Karahan et al., 2009). However, Coagulase-Negative Staphylococci (CNS) is also becoming an important problem for subclinical mastitis (Huxley et al., 2002; Taponen et al., 2006).

Mastitis is caused by various factors. Due to inflammation in the mammary gland some changes occur in the milk production as well as milk quality. The most important change is an increase in the number of leukocytes (white blood cells) in milk (Rajala-Schultz et al., 2004). Although subclinical mastitis has adverse effect on mammary gland tissue and creates inflammatory changes, no significant phenotypic clinical symptom occurs in the mastitis cow. Diagnosis of such mastitis could be done only using special clinical laboratory tests.
Early diagnosis has important role to prevent further spread of mastitis. Literature suggests that early treatment could decrease the disease (Baştan, 2013). Antibiotics are widely used in the treatment of such mastitis disease (Riffon et al., 2001; Phuektes et al., 2001). However, widespread use of antibiotics poses serious side effects, antibiotic resistance development and also antibiotic residues accumulates in the milk. Mastitis caused by antibiotic-resistant $S$. aureus is severe and could be transferred from animal to human either by direct contact or by food chain (Turutoglu et al., 2009). Widely used antibiotics in the successful treatment of mastitis could be screened by antibiotic susceptibility test. However it is hard to apply in the field conditions. Due to antibiotic resistance, $S$. aureus caused diseases have become hard to cure these days (Baştan, 2013). Therefore, it has become public health burden as well as economic loss. Reasoning this, it is an important and practical need to focus on discovering a new class of antimicrobial agent against such bacteria. 
Turkey is a rich country in terms of endemic plant species covering 10500 taxonomic habitats naturally. 3500 of these endemic plants has medical importance (Kaya and Raynal, 2001). L. orientalis is commonly known as sweet gum or Turkish sweet gum, is one of the endemic species having important medicinal values (Efe, 1987).

Hermaphrodite flowers of $L$. orientalis explode from March to April (Alan and Kaya 2003). Global blooming flower of L. orientalis is observed in saggy shape of 3-7 cm length, 1-2 cm diameter. The fruit contains woody covering large number of seeds (also called gumball) in 2$4 \mathrm{~cm}$ diameter. The height of the L. orientalis tree varies from 25 to $40 \mathrm{~m}$ and it has a straight body (Alan and Kaya 2003). To maintain the viability, height is necessary for this endemic plant species. The optimum height and required temperature for this plant species is $0-400 \mathrm{~m}$ and $18^{\circ} \mathrm{C}$ respectively (Alan and Kaya, 2003; Ickert-Bond et al., 2005). In order to maintain and protect, L. orientalis species is cultivated in a botanic garden in Dalyan and Koycegiz of Mugla, Turkey (Peşmen, 1972; Akbaş, 2011) in a special environment.

L. orientalis plant has great economic value because of its natural oil which is used in both cosmetic and pharmaceutical industries. In addition, oil has been previously reported to have anti-bacterial activity against many bacteria (Sağdıç et al., 2005). Sweet gum oil contains cinnamic acid, citrine, citrol, citron, storesinol and stirog (Küçükala et al., 2010). Sweet gum is reported to have anti-parasitic activity as well, and also therapeutic effective on skin diseases such as scabies and fungal dermatitis. Not limited to these but also it is used in the treatment of gastric problems (Küçükala et al., 2010).

So far, available literatures describe great importance of sweet gum oil of L. orientalis (Huş, 1949; Duru et al., 2002; Istek and Hafizoğlu, 2005) and its morphologic, anatomic, taxonomic, behavior and its application in tissue culture (Alan and Kaya, 2003; Fakir and Doganoğlu, 2003; Fakir, 2005). However, there was no study carried out yet to investigate the anti-bacterial activities of the extracts of $L$. orientalis against mastitis causing bacterial pathogens. Therefore, we investigated the anti-bacterial activity of leaf extract of $L$. orientalis against $S$. aureus and CNS isolated from mastitis cow. Anti-oxidant activities of leaf extracts were also determined.

\section{Materials and Methods}

L. orientalis plant was identified by Dr. Olcay Ceylan. Plant leaves were collected from Koycegiz, Mugla in 2012 at $10-15 \mathrm{~m}$ above sea level and were stored in herbaria (Herbarium No. 398), Department of Biology, Mugla Sitki Kocman University, Turkey. Plant extracts were made according to Davis (1965-1988).

Antibacterial effect of $L$. orientalis extracts was studied on 7 mastitis causing bacterial pathogens (2 S. aureus and 5 CNS) which was isolated previously by Dr. Zafer Cantekin (Project No: 1101 M 0103; Ethics Committee No: 2010/02-30:12). Identification of the bacterial strain was performed by conventional culture method using biochemical tests (Quinn et al., 1994).

In brief, fresh plant leaves were rinsed in running water 2-3 times followed by one more time in sterile distilled water. Washed leaves were dried first in the air and then triturated via shredder. All plant samples were stored initially at room temperature until sample was prepared. Prepared samples were further stored at $4^{\circ} \mathrm{C}$ until needed.

Acetone, methanol and ethanol were extracted from air-dried and powdered plant leaves with the help of Soxhlet apparatus. After evaporation of the extracts, each of them is preserved in their own solvent (methanol, ethanol and acetone) at refrigerator temperature until the use. Concentrations of each extract was adjusted as 40 $\mathrm{mg} / \mathrm{mL}$ in their own solvent and fully dissolved (Okmen et al., 2014).

Bacteria were incubated at $37^{\circ} \mathrm{C}$ in Mueller-Hinton Broth (MHB, Merck) medium for 24 hours. In all experiments, 18 hours active cultures were used. Turbidities of all bacterial cultures were adjusted according to $0.5 \mathrm{McF}$ arland.

Anti-bacterial activity of acetone, methanol and ethanol extracts of the plant leaves were tested by disc diffusion method using $40 \mathrm{mg} / \mathrm{mL}$ concentration (Okmen et al., 2014). All experiments were performed in triplicate. After incubation with extracts, the resulting bacterial inhibition zones were determined in millimeters $(\mathrm{mm})$. Acetone, methanol and ethanol were used as negative control because it acts as solvents for leaf extraction. Ampicillin $(10 \mu \mathrm{g})$ and Oxacillin $(5 \mu \mathrm{g})$ disks were also used as positive control in the experiments (Bauer et al., 1966). No anti-bacterial activity was observed for all negative controls (acetone, methanol and ethanol).

Anti-bacterial activity of leaves extracts was determined by calculating minimum inhibitory concentration (MIC). MIC was considered as the lowest concentration of the extracts that was able to inhibit the bacterial growth. Broth dilution method was performed using different concentrations $(6.5,3.2,1.6,0.8$ and 0.4 $\mu \mathrm{g} / \mathrm{mL}$ ) of each extract (CLSI 2003; CLSI 2006).

Antioxidant activity of leaves extract was determined by ABTS radical scavenging [2,2'-azino-bis (3-ethyl benzothiazoline-6-sulfonic acid)] assay as described by (Re et al., 1999). Radical scavenging activity was determined at 15 minutes incubation with $40 \mathrm{mg} / \mathrm{mL}$ extracts. As per literature, $7 \mathrm{mM}$ prepared solvent of ABTS radical was mixed with $2.4 \mathrm{mM}$ potassium persulphate solution. In order to obtain stability of ABTS radical, mixture was left in dark for 12-16 hours. Later, 10 $\mu \mathrm{L}$ extract solution was added into $1 \mathrm{~mL}$ of stable ABTS radical. Absorbance of this mixture (extract solution + stable ABTS radical) incubated for 15 minutes was measured at wavelength $734 \mathrm{~nm}$. \% ABTS ratios were determined with absorbance values as per given formulae.

$$
\% A B T S=\frac{A_{0}-A_{1}}{A_{0}} \times 100
$$


$\mathrm{A}_{0}$ : absorbance of ABTS radical solution in the first minute

$\mathrm{A}_{1}$ : absorbance of sample and ABTS radical solution in 15 minutes

Trolox was used as positive control for radical scavenging activities. Result obtained with Trolox was determined in $\mathrm{mM}$ Trolox equivalent (TE) as (TE)/g biomass. To obtain Trolox standard curve ( $\mathrm{pH} 7.4)$, different concentrations of solvents were prepared $(0.25$, $0.5,1,1.5,2,2.5 \mathrm{mM})$ in $5 \mathrm{mM}$ phosphate buffer saline (PBS) and absorbance of these samples were measured as described by (Miller et al., 1993). Each extracts were used in triplicate in the experiments and mean was calculated $(n=3)$.

\section{Results}

Forty $\mathrm{mg} / \mathrm{mL}$ of acetone, methanol and ethanol extracts of $L$. orientalis leaves were tested against $S$. aureus and CNS strains isolated from subclinical mastitis cows. Anti-bacterial impact of different extracts as well reference antibiotics shown in (Table 1) was determined in terms of inhibition zone diameter.

All extracts derived from $L$. orientalis leaves in 3 different solvents were able to show significant antibacterial property against mastitis causing bacteria.
However, anti-bacterial activity of these extracts was significantly lower towards CNS species compared to $S$. aureus. The highest anti-bacterial activity $(12 \mathrm{~mm}$ inhibition zone diameter) was observed for S. aureus 17 with acetone extracts. Interestingly but almost similar anti-bacterial properties (11 $\mathrm{mm}$ inhibition zone diameter) were also observed for methanol and ethanol extracts towards $S$. aureus 17 . The lowest anti-bacterial activity (7 $\mathrm{mm}$ inhibition zone diameter) of acetone extracts was found towards CNS-36 shown in the (Table 1).

MIC of different solvent extracts determined by broth dilution method is mentioned in (Table 2). $3.2 \mathrm{mg} / \mathrm{mL}$ was determined as the lowest MIC for all $S$. aureus and CNS (Table 2).

Furthermore, data mentioned in (Table 3) shows antioxidant activities of $L$. orientalis leaf extracts (40 $\mathrm{mg} / \mathrm{mL}$ ). Percentage ABTS radical scavenging capacity was determined in relation to positive control Trolox equivalent (TE). Radical scavenging capacities of all solvents were nearly the same. The highest radical scavenging activity (92.7\%) was observed in methanol extract. Trolox equivalent (TE) for all extracts was nearly the same. The highest Trolox equivalent (TE) observed was $2.58 \mathrm{mM} / \mathrm{g}$ in methanol extract shown in the (Table 3).

Table 1 The anti-bacterial activities of $L$. orientalis against mastitis pathogens

\begin{tabular}{l|ccccc}
\hline \multirow{2}{*}{ Bacteria } & \multicolumn{4}{c}{ Inhibition zone diameters (mm) } \\
\cline { 2 - 6 } & \multicolumn{3}{|c}{ Leaf extracts (40 mg/mL) } & \multicolumn{2}{c}{ Antibiotics } \\
\cline { 2 - 6 } & Acetone & Methanol & Ethanol & A & O \\
\hline S. aureus- 17 & 12 & 11 & 11 & 18 & 10 \\
S. aureus- 18 & 11 & 11 & 10 & 12 & 8 \\
CNS- 22 & 9 & 10 & 9 & - & - \\
CNS- 32 & 10 & 10 & 10 & 10 & 7 \\
CNS- 33 & 9 & 8 & 8 & 8 & 7 \\
CNS- 36 & 7 & 10 & 8 & - & - \\
CNS- 37 & 11 & 10 & 10 & - & - \\
\hline
\end{tabular}

CNS: Coagulase Negative Staphylococcus, A: Ampicillin, O: Oxacillin, (-): No inhibition

Table 2 MICs of L. orientalis leaf extracts

\begin{tabular}{l|ccc}
\hline \multirow{2}{*}{ Bacteria } & \multicolumn{3}{c}{ Leaf extracts $(40 \mathrm{mg} / \mathrm{mL})$} \\
\cline { 2 - 4 } S. aureus- 17 & Acetone & Methanol & Ethanol \\
S. aureus- 18 & 3.2 & 3.2 & 3.2 \\
CNS- 22 & 3.2 & 3.2 & 3.2 \\
CNS- 32 & 3.2 & 3.2 & 3.2 \\
CNS- 33 & 3.2 & 3.2 & 3.2 \\
CNS- 36 & 3.2 & 3.2 & 3.2 \\
CNS- 37 & 3.2 & 3.2 & 3.2 \\
\hline
\end{tabular}

CNS: Coagulase Negative Staphylococcus

Table 3 ABTS radical scavenging activities of $L$. orientalis leaf extracts

\begin{tabular}{l|ccc}
\hline \multirow{2}{*}{ Anti-oxidant activity } & \multicolumn{3}{c}{ Leaf extracts $(40 \mathrm{mg} / \mathrm{mL})$} \\
\cline { 2 - 4 } & Acetone & Methanol & Ethanol \\
\hline ABTS $(\%)$ & 91.8 & 92.7 & 91.9 \\
\hline Trolox equivalent $(\mathrm{mM} / \mathrm{g})$ & 2.51 & 2.53 & 2.58 \\
\hline
\end{tabular}




\section{Discussion}

Previous studies suggest that styrene, $\alpha$-pinene and $\beta$ pinene are the chemical components of L. orientalis (Fernandez et al., 2005). Trans-cinnamyl alcohol, hydroxy-cinnamyl and styrene as main component of this plant has been also reported previously. Volatile chemical constituents of American sweet gum constitute cinnamyl cinnamate, 3-phenyl propyl cinnamate, cinnamic acid, cinnamyl alcohol, 3-phenyl propyl alcohol and kariofilen (Chalchat et al., 1994). Previous studies suggests that essential oils, terpinen-4-ol, $\alpha$-terpineol, sabinene and $\gamma$ terpinene with cinnamyl cinnamete, phenyl propyl cinnamate, cinnamyl alcohol, ethyl cinnamide, methyl cinnamate and cinnamyl acetate are main constituent of $L$. orientalis (Hafizoglu, 1982; Hafizoglu et al., 1996; Duru and Çakır, 2002; Fernandez et al., 2005; Sagdıç et al., 2005; Hovaneissian et al., 2008). Cinnamic acid and most of its derivatives were also reported to show antimicrobial property against many microorganisms (Said et al., 2004; Sagdic et al., 2005). Siğla storax has inhibitory effect against 20 bacteria. Furthermore, main constituents of Liquidambar resina have been reported to have pharmacological effect against tumor, platelet precipitation and arrhythmic (Yang et al., 2011).

We investigated anti-bacterial activities of acetone, methanol and ethanol extracts of L. orientalis against 7 Staphylococci isolated from subclinical cow mastitis. Our result mentioned in Table 1 demonstrates the antibacterial effect of the extracts of $L$. orientalis against $S$. aureus causing mastitis in cow also supports the previous study reports of researchers who showed the anti-bacterial effect of $L$. orientalis extracts anti-bacterial effect against S. aureus (Oskay et al., 2009; Okmen, 2013a; Okmen et al., 2013b; Ergun et al., 2014; Okmen et al., 2016)

In this study, acetone extract shows the lowest antibacterial activity against CNS-36 mentioned in Table 1. Okmen (2013a) reported that Anthemis chia showed the lowest antibacterial activity against CNS-36. This report supports our work. Previous report Obasola et al., (2010) also suggests that CNS pathogens resist most of the antibiotics. CNS pathogens have many genes in their plasmids that may resist many antibiotics as well as they can negatively affect species barrier leading to the spread easily among different species. Kloos and Bannerman (1994) also reported that CNS can resist diverse antimicrobial agents.

Our comparative anti-bacterial effect results of all extracts demonstrate that acetone extract of $L$. orientalis had highest and superior anti-bacterial effect towards all bacteria than other extracts. Broad anti-bacterial effects of Liquidambar formosana have been also reported against Staphylococcus aureus, Staphylococcus epidermidis, Shigella flexneri, Salmonella Typhi and Pseudomonas aeruginosa (Zhong et al., 2007). Okmen (2013a) reported that Anthemis chia methanol extract was showed the highest inhibition zone against $S$. aureus-17. Okmen and Turkcan (2013b) reported that methanol extracts of Elaeagnus angustifolia have inhibitory effect against $S$. aureus-17. The inhibition zone was $20 \mathrm{~mm}$. Ergun et al.,
(2014) determined that methanol extract of Arbutus andrachne has $17 \mathrm{~mm}$ inhibition zone against $S$. aureus17. Okmen et al., (2016) reported that aqueous extract of Crocus sativus has $11 \mathrm{~mm}$ inhibition zone against CNS32. These results support our work.

Antioxidant activity of $L$. orientalis is mentioned in Table 3 as ABTS radical scavenging capacity as an experimental read out. Radical scavenging capacities of all solvents were almost similar. The highest radical scavenging capacities observed was $91.9 \%$ for the leaf ethanol extract depicted in (Table 3). In another study $L$. formosana essential oils have been shown as powerful antioxidant (Liu et al., 2009). Previous studies shows that various extracts of different plants have less antioxidant activity than L. orientalis. For example, Anthemis chia (82\%, Okmen 2013a), Elaeagnus angustifolia (84\%, Okmen and Turkcan, 2013b), Arbutus andrachne (81\%, Ergun et al., 2014), and Crocus sativus (84\%, Okmen et al., 2016).

Our study concludes here that $L$. orientalis leaf extracts exert potential anti-bacterial activities against $S$. aureus and CNS strains isolated from subclinical cow mastitis. As a result, MIC values were found to be effective even with very low concentration of leaves extracts. Our further analysis was to show anti-oxidant activities of these extracts. Our result shows significant anti-oxidant property of these extracts. Our study claims that $L$. orientalis could be useful in the treatment of subclinical cow mastitis as well many other bacterial infections as a new class of therapeutic medicines. This important plant has diverse medicinal value. It could be applied in antiseptic solution. Furthermore, leaf extracts of $L$. orientalis has importance of high anti-oxidant activities.

\section{Acknowledgement}

Authors thank Dr. Olcay Ceylan (University of Mugla Sitki Kocman, Department of Biology, Turkey) for the identification of this important medicinal plant.

\section{References}

Akbas K. 2011. Floristik properties of L. orientalis Mill. forests naturally distributed in Mugla province. MSKÜ Institute of Science and Technology. M Sci Thesis. Mugla.

Alan M, Kaya Z. 2003. EUFORGEN, Technical guidelines for genetic conservation and use for oriental sweet gum (Liquidambar orientalis). Intern Plant Gen Resour Inst., ISBN 92-9043-605-0. Rome, Italy. 6 pages.

Baştan A. 2013. İneklerde meme hastalıkları. Hatiboğlu Basımevi. ISBN 9789758322152. Ankara. 193 sayfa.

Bauer AW, Kirby WM, Sheris JC, Turck M. 1966. Antibiotic susceptibility testing by a standardized single disc method. Am J Clin Pathol., 45: 149-158.

Bramley AJ, Cullor JS, Erskine RJ, Harmon RJ, Hogan JS, Nickerson SC, Oliver SP, Smith KL, Sordillo LM. 1996. Current Concepts of Bovine Mastitis. 4th ed. National Mastitis Council, Madison, WI. 1996.

Chalchat JC, Garry RP, Mathieu JP. 1994. Composition of the volatile fraction from honduras styrax, Liquidambar styraciflua L. J Essent Oil Res., 6(1): 73-75. 
CLSI (Clinical and Laboratory Standards Institute). 2003. Methods for dilution antimicrobial susceptibility test for bacteria that grow aerobically, Approved standard M7-A, 6th edn. NCCLS, Wayne, Philadelphia.

CLSI (Clinical and Laboratory Standards Institute). 2006. Performance standards for antimicrobial susceptibility testing, $16^{\text {th }}$ Informational supplement M100-S16, NCCLS, Wayne, Philadelphia.

Davis PH. 1965-1988. Flora of Turkey and the East Aegean Islands. I-X. Edinburg Unv. Press. Edinburg.

Duru ME, Çakır A, Harmandar M. 2002. Composition of volatile oils isolated from the leaves of Liquidambar orientalis Mill. var. orientalis and L.orientalis var. integriloba from Turkey. Flav Frag J., 17(2): 95-98.

Efe A. 1987. Studies on the morphological and palynological characteristics of Liquiambar orientalis Mill. in Turkey. I. U. Orm. Fak. Derg., 37(2): 273-286.

Ergun N, Okmen G, Yolcu H, Cantekin Z, Ergun Y, Isık D, Sengul P. 2014. The enzymatic and non-enzymatic antioxidant activities of Arbutus andrachne L. leaf and flower and its antibacterial activities against mastitis pathogens. Eur J Exp Bio., 4(1): 227-232.

Fakir H. 2005. Isparta sığla ormanı tabiatı koruma alanı anıt ağaçları. S.D.Ü. Orm. Fak. Derg., A(1): 25-36.

Fakir H, Doğanoğlu O. 2003. Isparta Sığla (Liquidambar orientalis Mill.) orman tabiatı koruma alanı bitki taksonları. SDÜ Orm Fak Derg., A(1): 67-86.

Fernandez X, Lizzani-Cuvelier L, Loiseau AM, Perichet C, Delbecque C, Arnaudo JF. 2005. Chemical composition of the essential oils from Turkish and Honduras styrax. Flav Fragr J., 20: 70-73.

Hafizoglu H. 1982. Analytical studies on the balsam of Liquidambar orientalis Mill. by gas chromatography and mass spectroscopy. Holzforschung. 36: 311-313.

Hafizoglu H, Reunanen M, Istek A. 1996. Chemical composition of levent storax. Holzforschung. 50: 116-117.

Hovaneissian M, Archier P, Mathe C, Culioli G, Viellescazes C. 2008. Analytical investigation of styrax and benzoin balsams by HPLC-PAD-fluorimetry and GCMS. Phytochem Anal., 19: 301-310.

Huş S. 1949. Sığla ağacının Liquidambar orientalis Mill. ormancılık bakımından önemi ve sığla yağının kimyasal araştırılması. Orm Gn Müd Yayını, 83: 7-61.

Huxley JN, Green MJ, Green LE, Bradle AJ. 2002. Evaluation of the efficacy of an internal teat sealer during the dry period. $J$ Dairy Sci., 85: 551-561.

Ickert-Bond SM, Pigg KB and Wen J. 2005. Comparative infructescence morphology in Liquidambar (Altingiaceae) and its evolutionary significance. Am J Botany, 92(8): 1234-1255.

Istek A, Hafızoğlu H. 2005. Sığla ağacı (Liquidambar orientalis Mill.) odunu kabuğunun kimyasal bileşenleri. G.Ü. Kastamonu Orm Fak Derg., 5:1.

Karahan M, Açık MN, Çetinkaya B. 2009. Investigation of toxin genes by polymerase chain reaction in Staphylococcus aureus strains isolated from bovine mastitis. Foodborne Pathog Dis., 6: 1-7.

Kaya Z, Raynal DJ. 2001. Biodiversity and conservation of Turkish forests. Biol Conserv., 97(2): 131-141.

Kloos WE, Bannerman TL. 1994. Update on clinical significance of coagulase-negative Staphylococci. Clin Microb Rev., 7(1): 117 40.

Küçükala A, Durmuşkahya C, Koray Z. 2010. Sığla ağacının korunmasına yönelik eğitim çalışmaları projesi sonuç raporu. Ö.Ç.K.K. Başkanlığı. Ankara.

Liu Y, Liu Y, Li P. 2009. Study on antimicrobial activities of essential oil from leaves of Liquidambar formosana Hance as well as its anti-oxidant activity. Food Sci., 30(11): 134-137.

Miller NJ, Rice-Evans C, Davies MJ, Gopinathan V, Milner A. 1993. A novel method for measuring anti-oxidant capacity and its application to monitoring the anti-oxidant status in premature neonates. Clin. Sci., 84: 407-412.
Obasola EF, Cajethan OE, Abolade AO, Adeniyi AO. 2010. Comparative study of antibiotic resistance of Staphylococcus species isolated from clinical and environmental samples. AUJ Techn., 13(3): 165-169.

Okmen G. 2013a. The antibacterial activity of Anthemis chia L. flower against mastitis pathogens and antioxidant capacity of the various extracts. JFAE., 11(3\&4): 795-799.

Okmen G, Kardas S, Bayrak B, Arslan A, Cakar H. 2016. The antibacterial activities of Crocus sativus against mastitis pathogens and its antioxidant activities. WJPPS., 5(3): 146-156.

Okmen G, Turkcan O. 2013b. The antibacterial activity of Elaeagnus angustifolia L. against mastitis pathogens and antioxidant capacity of the leaf methanolic extracts. J. Anim. Vet. Adv., 12(4): 491-496.

Okmen G, Turkcan O, Ceylan O, Gork G. 2014. The antimicrobial activity of Liquidambar orientalis Mill. against food pathogens and antioxidant capacity of leaf extracts. Afr. J. Tradit. Complement. Altern. Med., 11(5): 28-32.

Oskay M, Oskay D, Kalyoncu F. 2009. Activity of some plant extracts against multi-drug resistant human pathogens. Iran J Pharm Res., 8(4): 293-300.

Peşmen H. 1972. Flora of Turkey and the East Aegean Islands. In: Davis PH (Eds): Proc. Edinburgh Univ. Press. Edinburgh. 4: 440-453.

Phuektes P, Mansell PD, Browning GF. 2001. Multiplex polymerase chain reaction assay for simultaneous detection of Staphylococcus aureus and Streptococcal causes of bovine mastitis. J Dairy Sci., 84: 1140-1148.

Quinn PJ, Carter ME, Markey BK, Carter GR. 1994. Clinical Veterinary Microbiology. Mosby-Year Book Europe Limited, London, England. 209-236 p.

Rajala-Schultz PJ, Smith KL, Hogan JS, Love BC. 2004. Antimicrobial susceptibility of mastitis pathogens from first lactation and older cows. Vet Microbiol., 102: 33-42.

Re R, Pellegrini N, Proteggente A, Pannala A, Yang M, Rice-Evans C. 1999. Anti-oxidant activity applying an improved ABTS radical cation decolorization assay. Free Radic Biol Med., 26: 1231-1237.

Riffon R, Sayasith K, Khalil H, Dubreuil P, Drolet M, Lagace J. 2001. Development of a rapid and sensitive test for identification of major pathogens in bovine mastitis by PCR. J Clin Microbiol., 7 : 2584-2589.

Sağdıç O, Özkan G, Özcan M, Özçelik S. 2005. A Study on inhibitory effects of siğla tree (Liquidambar orientalis Mill. var. orientalis) storax against several bacteria. Phytother Res., 19: 549-551.

Said S, Neves FM, Griffiths AJF. 2004. Cinnamic acid inhibits the growth of the fungus Neurospora crassa, but is eliminated as acetophenone. Intern Biodeter Biodeg., 54: 1-6.

Taponen S, Simojoki H, Haveri M, Larsen HD, Pyorala, S. 2006. Clinical characteristics and persistence of bovine mastitis caused by different species of coagulase-negative staphylococci identified with API or AFLP. Vet Microbiol., 115: 199-207.

Turutoglu H, Hasoksuz M, Ozturk D, Yildirim M, Sagnak S. 2009. Methicillin and aminoglycoside resistance in Staphylococcus aureus isolates from bovine mastitis and sequence analysis of their mecA genes. Vet Res Commun., 33: 945-956.

Watts JL. 1988. Etiological agents of bovine mastitis. Vet Microbiol., 16: 41-66.

Wellenberg GL, Van der Poel WHM, Van Orschot JT. 2002. Viral infections and bovine mastitis. Vet Microbiol., 88: 27-45.

Yang NY, Chen JH, Zhou GS, Tang YP, Duan JA, Tian LJ, Liu XH. 2011. Pentacyclic triterpenes from the resin of Liquidambar formosana. Fitoterapia. 82(6): 927-31.

Zhong YT, Wang XL, Ma LL. 2007. Studies on antimicrobial activity of Liquidambar formosana Hance's leaf. Lishizhen Medic. Materia. Medica. Res., 18: 1693-1694. 